\title{
PERTUMBUHAN DAN PRODUKSI TANAMAN SAWI (Brassica juncea L.) PADA BERBAGAI BOKASHI ECENG GONDOK
}

\author{
Asrijal \\ Fakultas Pertanian Universitas Puangrimaggalatung Sengkang \\ Email: rijalku238@gmail.com
}

\begin{abstract}
Ringkasan
Penelitian bertujuan mengetahui pertumbuhan dan produksi tanaman sawi (Brassica juncea L.), pada berbagai bokashi eceng gondok. Penelitian dilaksanakan dengan menggunakan Rancangan Acak kelompok terhadap empat macam bokashi eceng gondok yaitu tanpa bokashi eceng gondok, bokashi eceng gondok kotoran ayam pedaging, bokashi eceng gondok kotoran sapi, dan bokashi eceng gondok kotoran ayam kampung. Setiap perlakuan diulang sebanyak tiga kali sehingga jumlah kombinasi perlakuan sebanyak 12 kombinasi. Hasil penelitian menunjukkan bahwa Aplikasi bokashi eceng gondok kotoran ternak ayam kampung memperlihatkan hasil yang nyata dan tertinggi pada jumlah daun dan bobot segar tanaman sawi masing-masing sebesar 9.51 helai dan 27,79 g/tanaman, dibandingkan dengan perlakuan lainnya.
\end{abstract}

Kata Kunci: tanaman sawi, bokashi eceng gondok, kotoran ternak 


\title{
GROWTH AND PRODUCTION OF SAWI (Brassica Juncea L.) PLANTS IN VARIOUS WATER HYACINTH BOKASHI
}

\begin{abstract}
The study aims to determine the growth and production of mustard plants (Brassica juncea L.), in various water hyacinth bokashi. The study was conducted using a randomized block design (RBD) on four kinds of water hyacinth bokashi (b), ie without water hyacinth bokashi (b0), water hyacinth bokashi broiler dung (b1), bokashi water hyacinth cow dung (b2), and water hyacinth bokashi village chicken manure goiter (b3). Each treatment was repeated three times so that the number of treatment combinations was 12 combinations. The results showed that the application of water hyacinth bokashi native chicken manure showed the highest and most obvious results on the number of leaves and fresh weight of mustard plants respectively by 9.51 strands and $27.79 \mathrm{~g} /$ plant, compared with other treatments.
\end{abstract}

Keywords: mustard plant, water hyacinth bokashi, livestock manure

\section{PENDAHULUAN}

Pertanian organik merupakan bagian dari pertanian alami yang dalam pelaksanaannya berusaha menghindarkan penggunaan bahan kimia dan pupuk yang bersifat meracuni lingkungan dengan tujuan untuk memperoleh kondisi lingkungan yang sehat. Selain itu, juga untuk menghasilkan produksi tanaman yang berkelanjutan dengan cara memperbaiki kesuburan tanah melalui penggunaan sumberdaya alami seperti mendaur ulang limbah pertanian. Dalam pelaksanaannya, pertanian organik adalah membatasi ketergantungan petani pada penggunaan pupuk anorganik dan bahan kimia pertanian lainnya. Pupuk anorganik yang selalu digunakan petani dapat diganti dengan pupuk organik yang dapat dibuat sendiri dari bahan-bahan alami seperti penggunaan pupuk kandang yang mudah didapat dan kadang tidak dimanfaatkan oleh masyarakat yang memiliki ternak.

Tanaman Sawi termasuk jenis tanaman sayuran dan tergolong kedalam tanaman semusim (berumur pendek). Masyarakat banyak menanam tanaman ini di pekarangn rumah mereka karena tanaman ini tidak membutuhkan banyak tempat untuk hidupnya jika untuk di konsumsi sendiri. Oleh masyarakat tanaman ini juga sering digunakan sebagai bahan makanan karena banyak mengandung zat-zat yg dibutuhkan oleh tubuh kita. Sebagai sayuran, caisim atau dikenal dengan sawi hijau mengandung berbagai khasiat bagi kesehatan. Kandungan yang terdapat pada caisim adalah protein, lemak, karbohidrat, Ca, P, Fe, Vitamin A, Vitamin B, dan Vitamin C (Fahrudin, 2009 dan Dwi, 2005).

Menurut Wolverton (1978 dalam Asrijal, 2004), perkembangbiakan eceng gondok dilakukan secara vegetatif, batang secara kontinu menghasilkan daun baru yang muncul pada pusat pembungaan. Pada dasar setiap tangkai daun terdapat satu tunas yang berkembang menjadi tangkai baru dan menghasilkan akar yang mempunyai banyak cabang. Calon daun berkembang pada pangkal batang (ketiak) induknya dan akhirnya menjadi tunas yang berkembang menjadi batang bersama akarnya. Pertumbuhannya mulamula horizontal dan apabila permukaan danau atau kolam telah tertutup dengan rapat maka pertumbuhan terjadi secara vertikal yang dapat mencapai ketinggian 1,20 m. Eceng gondok merupakan tanaman semiakuatik dan dapat mengapung di perairan berkat batang yang berongga. Konsekuensi dari sifat pertumbuhannya yang cepat dan intensif adalah membawa dampak negatif terhadap pencemaran dalam penutupan waduk, kolam, danau, dan bendungan yang bersifat biofisik. 
Bokashi dapat digunakan untuk produksi tanaman meskipun bahan organiknya belum terurai seperti pada kompos. Bokashi dapat dibuat secara cepat dengan adanya mikroorganisme yang menfermentasikan bahan organik selama $3-4$ hari dan langsung dapat digunakan sebagai pupuk organik. Bahan organik untuk bokashi sangat banyak terdapat di sekitar lahan pertanian seperti jerami, pupuk kandang, rumput, pupuk hijau, sekam, dedak, serbuk gergaji, ampas tebu, dan arang. Namun dedak padi sangat dianjurkan sebagai bahan penting untuk bokashi, karena mengandung gizi yang baik untuk mikroorganisme. Akan lebih baik lagi apabila campuran bahan organik yang mempunyai perbandingan karbon dan nitrogen $(\mathrm{C} / \mathrm{N}$ rasio) yang rendah dan yang tinggi. Biasanya untuk meningkatkan keragaman mikroba, penggunaan paling sedikit 3 macam bahan organik sangat dianjurkan (Wididana dan Teruo, 1996 dalam Asrija et al., 2005).

Penggunaan bokashi merupakan salah satu cara untuk meningkatkan kesuburan fisik, kimia, dan biologi tanah dan dapat meningkatkan produksi (Asrijal, 2004 dan Asrijal et al., 2005). Namun demikian jenis dan dosis bokashi yang dibutuhkan tanaman sangat bervariasi, tergantung varietasnya, ketersediaan bahan, dan kondisi tanah. Keuntungan menggunakan bokashi adalah efisiensinya tinggi, tidak mengganggu keseimbangan hara dalam tanah, memperbaiki sifat fisik, kimia, dan biologi tanah sehingga meningkatkan produktivitas lahan. Oleh karena itu pemanfaatan pupuk organik perlu diterapkan sebagai akibat harga pupuk anorganik yang mahal dan untuk menciptakan lahan pertanian yang lebih berkelanjutan (Farid, 2003).

\section{METODE PENELITIAN}

Penelitian dilaksanakan di Kelurahan Wiringpalennae Kecamatan Tempe Kabupaten Wajo. Rancangan yang digunakan adalah Rancangan Acak Kelompok (RAK), terdiri atas empat (4) perlakuan yaitu tanpa Bokashi Eceng Gondok (BEG) $\left(b_{o}\right)$, BEG kotoran ayam pedaging $\left(b_{1}\right)$, BEG kotoran sapi $\left(b_{2}\right)$, dan BEG kotoran ayam kampung $\left(b_{3}\right)$. Setiap perlakuan diulang sebanyak tiga kali sehingga jumlah kombinasi perlakuan sebanyak 12 kombinasi (12 petakan perlakuan), sedangkan luas setiap petakan yaitu 1 meter 1,2 meter. Bokashi Eceng Gondok yang digunakan adalah BEG yang sudah jadi satu bulan sebelumnya yang merupakan hasil praktek lapang mahasiswa semester 4 (empat) program studi Agroteknologi Faperta Uniprima Sengkang. Parameter yang diamati yaitu: Jumlah daun (helai) adalah banyaknya jumlah daun tanaman sawi umur 40 hari yang dihitung secara manual. Dan Berat basah (g/tanaman) adalah berat segar pada setiap tanaman sawi, yang diukur dengan timbangan analitik. Pengolahan data hasil pengukuran di lapangan melalui Analysis of Variance (ANOVA), dan dilakukan Analisis Uji Beda Nyata Jujur (BNJ) pada taraf $5 \%$ (Gaspersz, 1991).

\section{HASIL DAN PEMBAHASAN}

\section{Hasil}

\section{Jumlah Daun}

Hasil penelitian menunjukkan bahwa jumlah daun umur 40 hari setelah tanam pada tanaman sawi, memperlihatkan pengaruh yang sangat nyata terhadap jumlah daun umur 40 hari setelah tanam. Hasil Uji BNJ menunjukkan bahwa perlakuan $b_{0}$ berbeda nyata dengan perlakuan $b_{3}$, akan tetapi berbeda tidak nyata dengan perlakuan $b_{1}$ dan $b_{2}$, sedangkan perlakuan $b_{1}, b_{2}$, dan $b_{3}$, masing-masing memperlihatkan perbedaan yang tidak nyata, terhadap jumlah daun umur 40 hari setelah tanam pada tanaman sawi (Tabel 1). 
Tabel 1. Rata-rata jumlah daun umur 40 hari setelah tanam pada tanaman sawi (helai).

\begin{tabular}{cccc}
\hline Perlakuan & Rata-rata & Hasil Uji & Uji Beda $(\mathrm{BNJ}-\mathrm{a}=0,05)$ \\
\hline $\mathrm{b}_{0}$ & 5,60 & $\mathrm{~b}$ & \\
$\mathrm{~b}_{1}$ & 8,09 & $\mathrm{ab}$ & 3,00 \\
$\mathrm{~b}_{2}$ & 7,93 & $\mathrm{ab}$ & \\
$\mathrm{b}_{3}$ & 9,51 & $\mathrm{a}$ & \\
\hline
\end{tabular}

Keterangan : Rata-rata yang diikuti oleh huruf yang sama berarti berbeda tidak nyata pada taraf $\alpha$ $=0,05$

\section{Bobot Segar}

Hasil penelitian menunjukkan bahwa bobot segar umur 40 hari setelah tanam pada tanaman sawi, memperlihatkan pengaruh yang sangat nyata terhadap bobot segar umur 40 hari setelah tanam. Hasil Uji BNJ, menunjukkan bahwa perlakuan $b_{0}$ berbeda nyata dengan perlakuan lainnya, perlakuan $b_{1}$ berbeda tidak nyata dengan perlakuan $b_{2}$, akan tetapi berbeda nyata dengan perlakuan $b_{3}$. Perlakuan $b_{2}$ memperlihatkan perbedaan yang nyata dengan perlakuan $b_{3}$, terhadap bobot segar umur 40 hari setelah tanam pada tanaman sawi (Tabel 2).

Tabel 2. Rata-rata bobot segar umur 40 hari setelah tanam pada tanaman sawi (g/tanaman).

\begin{tabular}{cccc}
\hline Perlakuan & Rata-rata & Hasil Uji & Uji Beda $(\mathrm{BNJ}-\mathrm{a}=0,05)$ \\
\hline $\mathrm{b}_{0}$ & 6,20 & $\mathrm{C}$ & \\
$\mathrm{b}_{1}$ & 18,57 & $\mathrm{~B}$ & 3,30 \\
$\mathrm{~b}_{2}$ & 17,40 & $\mathrm{~B}$ & \\
$\mathrm{~b}_{3}$ & 27,79 & $\mathrm{~A}$ & \\
\hline
\end{tabular}

Keterangan : Rata-rata yang diikuti oleh huruf yang sama berarti berbeda tidak nyata pada taraf $\alpha=0,05$

\section{Pembahasan}

Pertumbuhan dan perkembangan suatu tanaman harus didukung oleh ketersediaan unsur hara, terutama unsur hara makro, disamping juga unsur mikro lainnya, guna mendukung proses pembentukan jaringan tanaman. Menurut Suhardjo et al. (1993), bahwa unsur hara makro sangat dibutuhkan tanaman untuk pertumbuhan sampai produksi dalam jumlah yang banyak terutama dalam proses pembentukan daun.

Hasil penelitian menunjukkan bahwa perlakuan bokashi eceng gondok dengan kotoran ayam kampung memberikan respon yang sangat baik dan nyata terhadap jumlah daun dan bobot segar tanaman sawi. Hal ini disebabkan karena bokashi memiliki kegunaan untuk meningkatkan kesuburan fisik, kimia, dan biologi tanah, disamping itu kotoran ternak ayam kampung memiliki kandungan $\mathrm{N}$ yang cukup tinggi. Sejalan dengan pendapat Asrijal, (2004) dan Asrijal et al., (2005) bahwa penggunaan bokashi merupakan salah satu cara untuk meningkatkan kesuburan fisik, kimia, dan biologi tanah dan dapat meningkatkan produksi. Namun demikian jenis dan dosis bokashi yang dibutuhkan tanaman sangat bervariasi, tergantung varietasnya, ketersediaan bahan, dan kondisi tanah. Keuntungan menggunakan bokashi adalah efisiensinya tinggi, tidak mengganggu 
keseimbangan hara dalam tanah, memperbaiki sifat fisik, kimia, dan biologi tanah sehingga meningkatkan produktivitas lahan. Oleh karena itu pemanfaatan pupuk organik perlu diterapkan sebagai akibat harga pupuk anorganik yang mahal dan untuk menciptakan lahan pertanian yang lebih berkelanjutan (Farid, 2003).

Menurut Soepardi (1983) menyatakan bahwa serapan unsur hara oleh tanaman sangat dipengaruhi oleh kadar dan ketersediaan hara dalam tanah dan serapan Nitrogen oleh tanaman berhubungan positif dan cukup erat dengan kadar Nitrogen tanah serta meningkatnya kadar Nitrogen dalam tanah akibat dari penambahan pupuk organik. Pemberian pupuk organik hasil perombakan anaerob dapat meningkatkan jumlah daun tanaman sawi, sehingga mempengaruhi bobot segar tanaman (Aisyah, 2011; Yasin et al., 2019). Naswir et al. (2009), mengatakan bahwa perlakuan fermentasi tidak saja memberikan pengaruh terhadap peningkatan konsentrasi unsur haranya, tetapi juga diharapkan bibit-bibit penyakit tanaman yang ada akan dapat dimatikan karena kondisi lingkungannya anaerob.

\section{KESIMPULAN DAN SARAN}

\section{Kesimpulan}

Berdasarkan hasil dan pembahsan, maka dapat disimpulkan bahwa Aplikasi bokashi eceng gondok dengan kotoran ternak ayam kampung memperlihatkan hasil yang nyata dan tertinggi pada jumlah daun dan bobot segar tanaman sawi masing-masing sebesar 9.51 helai dan 27,79 g/tanaman, dibandingkan dengan perlakuan lainnya.

\section{Saran}

Disarankan agar melakukan pengujian ulang pada variasi dosis bokashi eceng gondok kotoran ternak ayam kampong baik pada tanaman yang sama, maupun pada tanaman yang berbeda termasuk lokasi yang berbeda.

\section{DAFTAR PUSTAKA}

Aisyah, S. 2011. Pemberian fermentasi urine sapi terhadap pertumbuhan tanaman sawi (Brassica juncea L.) dengan dosis dan interval berbeda. Skripsi. Fakultas Pertanian dan Peternakan Universitas Islam Negeri Sultan Syarif Kasim Riau. Pekanbaru.

Asrijal, 2004. Penggunaan bokashi eceng gondok (Eichhornia crassipes) pada sistem pertanaman tunggal dan tumpangsari kedelai, jagung, dan padi gogo. Tesis. Pascasarjana Universitas Hasanuddin, Makassar

Asrijal, A.Muin Pabinru, dan Bachrul Ibrahim, 2004. Penggunaan bokashi eceng gondok pada sistem pertanaman tunggal dan tumpangsari jagung, dan padi gogo. J.Agrivigor $5(1): 72-84$

Dwi, Z.J., 2005. Bertanam Sawi Dalam Polybag. Warta Penelitian dan Pengembangan Pertanian Vol. 27. h. 5.

Fahrudin, F., 2009. Budidaya Caisim (Brassica junce L.) Menggunakan Ekstrak Teh Dan Pupuk Kscing. Skripsi, Universitas Sebelas Maret, Surakarta.

Farid, M., 2003. Pertumbuhan dan Produksi Kapas Transgenik Bt pada Berbagai

Gaspersz,.1991. Metode Perancangan Percobaan. Penerbit, CV. Armico, Bandung Indonesia. 
Naswir, S. H., H. P. Nora, dan P. Hidayat. 2009. Efektivitas sistem fertigasi mikro untuk lahan sempit. Jurnal Pascasarjana, 32 (1) : 45-54.

Soepardi, G.1983. Sifat dan Ciri Tanah. IPB Pers. Bogor.

Suhardjo, Soepartini, dan Kurnia, U. 1993. Bahan Organik Tanah Informasi Penelitian Tanah, Air, Pupuk dan Lahan. Pengembangan Penelitian, Pusat Penelitian Tanah dan Agroklimat, Bogor.

Yasin, S.M., Kasim, N.N., Sapareng, S., Jabal., 2019. Pengaruh Bioaktivator Dalam Proses Pengomposan Jerami Padi. Jurnal Tabaro, 3 (1) : 287-294 